\title{
DRY EYE IN PATIENTS WITH PTERYGIUM- A CROSS-SECTIONAL STUDY AT A TERTIARY CARE CENTRE IN THRISSUR
}

\author{
Deleep Kumar Kozhikkot Velayudhan'1, Suja George Valavi², Rajini K. Chereyath³, Rini Raveendran4
}

1 Professor and HOD, Department of Ophthalmology, Government Medical College, Manjeri, Kerala.

2Junior Consultant, Department of Ophthalmology, Taluk Hospital, Kunnamkulam, Kerala.

3 Professor and HOD, Department of Ophthalmology, Government Medical College, Thrissur, Kerala.

${ }^{4}$ Assistant Professor, Department of Community Medicine, Government Medical College, Manjeri, Kerala.

ABSTRACT
BACKGROUND
Pterygium is a degenerative condition of the eye, recorded since ancient times. ${ }^{1}$ It is
of the eye. The main disadvantage due to the disease is cosmetic. It also causes
extending over the visual axis.
Aims and Objectives of the study are-
1. To find out proportion of dry eye among patients with Pterygium.
2. To find out the factors associated with dry eye among patients with Pterygium.

\section{MATERIALS AND METHODS}

A cross-sectional study was done on patients with clinical diagnosis of Pterygium. Information was collected on age, sex, occupation, dietary habit, smoking, menstrual history and systemic illness. Ocular examination including refraction with special emphasis on Schirmer's test, Tear film Break-up Time, Tear Meniscus Height and Size of Pterygium was conducted. Data was entered into Microsoft Excel. Statistical analysis was made using Chi-Square test and Correlation.

\section{RESULTS}

- Dry eye condition was assessed on the basis of the tests. $20.32 \%$ of eyes on Schirmer's test, $35.77 \%$ of eyes on TBUT and $62.60 \%$ of eyes on TMH were found to have dry eye.

- Mean value of Schirmer's test was $16.70 \mathrm{~mm}$ on right eye and $18 \mathrm{~mm}$ on left eye.

- $\quad$ Mean value of TBUT was $10.2 \mathrm{sec}$ on right eye and $10.7 \mathrm{sec}$ on left eye.

- Mean value of TMH was $0.4 \mathrm{~mm}$ in both eyes.

- The Dry eye tests of right and left eyes did not show significant difference in the case of unilateral Pterygium.

- The association between Dry eye tests and presence of Pterygium also did not show any statistically significant association, except in the case of TBUT and Pterygium on right eye.

- Association between dry eye tests and risk factors was positive only in the case of aged.

- $\quad$ The Dry eye tests between right and left eyes showed strong correlation, irrespective of unilateral or bilateral Pterygium.

\section{CONCLUSION}

Dry eye condition is seen in at least $20.32 \%$ of eyes, but significant association between Dry eye and presence of Pterygium is not seen. Age showed positive association with Schirmer's test among the Pterygium patients. Also refractive error showed positive association with TBUT among the Pterygium patients.

\section{KEYWORDS}

Pterygium, Dry Eye, Schirmer's Test, TBUT, TMH.

HOW TO CITE THIS ARTICLE: Velayudhan DKK, Valavi SG, Chereyath RK, et al. Dry eye in patients with pterygium- a crosssectional study at a tertiary care centre in Thrissur. J. Evolution Med. Dent. Sci. 2018;7(06):774-778, DOI: $10.14260 /$ jemds/2018/176

\section{BACKGROUND}

Pterygium is a degenerative condition of the eye, recorded since ancient times. ${ }^{1}$ It is seen as a triangular patch on the exposed part of the eye. The main disadvantage due to the disease is cosmetic. It also causes vision defect due to either refractive error or extending over the visual axis.

'Financial or Other Competing Interest': None.

Submission 05-12-2017, Peer Review 20-01-2018,

Acceptance 27-01-2018, Published 05-02-2018.

Corresponding Author:

Suja George Valavi,

Valavi House,

Chalakkudi, Thrissur-680307.

E-mail:georgesujav@gmail.com

DOI: $10.14260 /$ jemds/2018/176
At present, the medical treatment is not satisfactory. The only effective approach is surgical, ${ }^{2}$ but there is chance of high recurrence rate. The major risk factor for Pterygium is ultraviolet B-light in sunlight. ${ }^{2}$

\section{Rationale}

In Kerala, Pterygium is a common disease. The people engaged in outdoor work are not routinely using hat or protective sunglass. Studies on the problem of Dry eye in patients with Pterygium give a wide range in different parts of the world. Study on the problem is not seen in Kerala. The present study aims to assess Dry eye condition in patients with Pterygium. 


\section{Objectives of the Study}

1. To find out the proportion of Dry eye in patients with Pterygium attending Ophthalmology Department at Government Medical College, Thrissur using various tests.

2. To find out the factors associated with Dry eye among these patients.

\section{MATERIALS AND METHODS \\ Study Design \\ Cross-sectional study.}

\section{Study Setting}

Department of Ophthalmology, Government Medical College, Thrissur.

\section{Study Period}

9 Months (01 ${ }^{\text {st }}$ Feb - 01 $1^{\text {st }}$ Nov 2015).

\section{Study Subjects}

Patients with Pterygium attending the Outpatient section at Department of Ophthalmology, Medical College, Thrissur.

\section{Inclusion Criteria}

Patients with clinical diagnosis of Pterygium and willing to participate in the study.

\section{Exclusion Criteria}

Patients with acute eye condition like watering, itching or pain are excluded. Those who had eye surgery within the last one month or awaiting surgery in the next few days.

\section{Sample Size}

100 , calculated using the formula $n=4 p q / d^{2}$,

\section{Where-}

$\mathrm{p}=$ prevalence of dry eye in patients with Pterygium, $50 \%$

$\mathrm{q}=100-\mathrm{p}$

$\mathrm{d}=$ clinically allowable error, which is $20 \%$ of prevalence.

Power of study at significance level of 0.05 is $80 \%$.

\section{Study Tools}

1. Pre-tested questionnaire.

2. External eye examination under torch light.

3. Slit lamp examination and direct ophthalmoscopy.

4. Schirmer's test without anaesthesia.

5. Tear film break-up time test.

6. Marginal tear film Meniscus Height.

\section{Methodology}

After obtaining informed consent, data was collected from each patient using a pre-tested questionnaire. Visual acuity, size of Pterygium, refractive power, Schirmer's test, Tear film Break-up Time and Tear Meniscus Height were assessed. Tests were done for each eye.

\section{Operational Definition \\ Occupation}

Working in sunlight at least 6 hours per day for at least 3 days per week was considered as outdoor occupation; other occupations as indoor.

\section{Diet}

Eating either fish or meat at least twice per week was considered as non-vegetarian; others as vegetarian.

Smoking: Smoking at least once per day was considered as smoking present; others as non-smoking.

1. Schirmer's Test I (Test without Anaesthesia)- Whatman No. 41 filter paper folded at one end, kept inside the lower eye lid at the junction of medial $2 / 3^{\text {rd }}$ and lateral $1 / 3^{\text {rd }}$. The patient was asked to keep the eyes open for 5 minutes. Gentle blinking was allowed if needed. At the end of 5 minutes, reading on the strip was taken. This data was then taken for analysis.

2. Tear film Break-up Time- Fluorescein strip was used to stain the tear film by keeping the chin on the slit lamp chinrest. Patient was asked to blink a few times, then to keep the eyes open. The tear film over the cornea was examined under cobalt blue filter with broad beam of slit lamp. Time taken between the last blink and the appearance of first dry spot was taken in seconds.

3. Tear Meniscus Height- The height of the tear meniscus is taken by directing the slit lamp beam towards the lower lid margin and adjusting the size of graticule to match the meniscus height.

4. Size of the Pterygium from the limbus to apex was taken by keeping the beam of slit lamp in the horizontal axis.

5. Dry eye was considered to be present on the basis of the tests:

Schirmer's test without anaesthesia : less than $10 \mathrm{~mm}$

TBUT : less than 10 seconds

TMH : less than $0.50 \mathrm{~mm}$

\section{Ethical Clearance and Conflict of Interests}

Study proposal was cleared by Institutional Research Board prior to beginning of data collection. There was no conflict of interests involved. There were no external funding sources.

\section{Data Analysis}

Collected data were coded and entered in Microsoft Excel 2010. Statistical analysis was done using Epi-Info 3.5. ChiSquare test was used to find association. $\mathrm{P}$ value less than 0.05 was considered as significant.

\section{RESULTS}

Out of estimated 100 patients with Pterygium on either one eye or both eyes, only 85 patients participated in the study, among which 29 were male and 56 were female patients.

\section{Size of Pterygium}

The overall mean values of size of Pterygium were 1.24 for right eye with mean values of 1.10 for males and 1.31 for females. It was 1.18 left eyes with mean values of 1.00 for males and 1.27 for females. 


\begin{tabular}{|c|c|c|c|c|c|c|}
\hline & \multicolumn{3}{|c|}{ RPRGY } & \multicolumn{3}{c|}{ LPTRGY } \\
\hline Age & Overall & Male & Female & Overall & Male & Female \\
\hline$<35$ & 0.84 & 1.50 & 0.40 & 1.24 & 2.00 & 0.73 \\
\hline $36-45$ & 0.86 & 0.77 & 1.00 & 0.74 & 0.66 & 0.86 \\
\hline $46-55$ & 1.55 & 1.95 & 1.44 & 0.88 & 0.75 & 0.91 \\
\hline $56-65$ & 1.28 & 1.28 & 1.28 & 1.42 & 0.93 & 1.45 \\
\hline$>66$ & 1.31 & 1.04 & 1.40 & 1.76 & 1.60 & 1.83 \\
\hline Table 1. Age-Wise Comparison of Mean Values of Size of \\
Pterygium \\
\hline
\end{tabular}

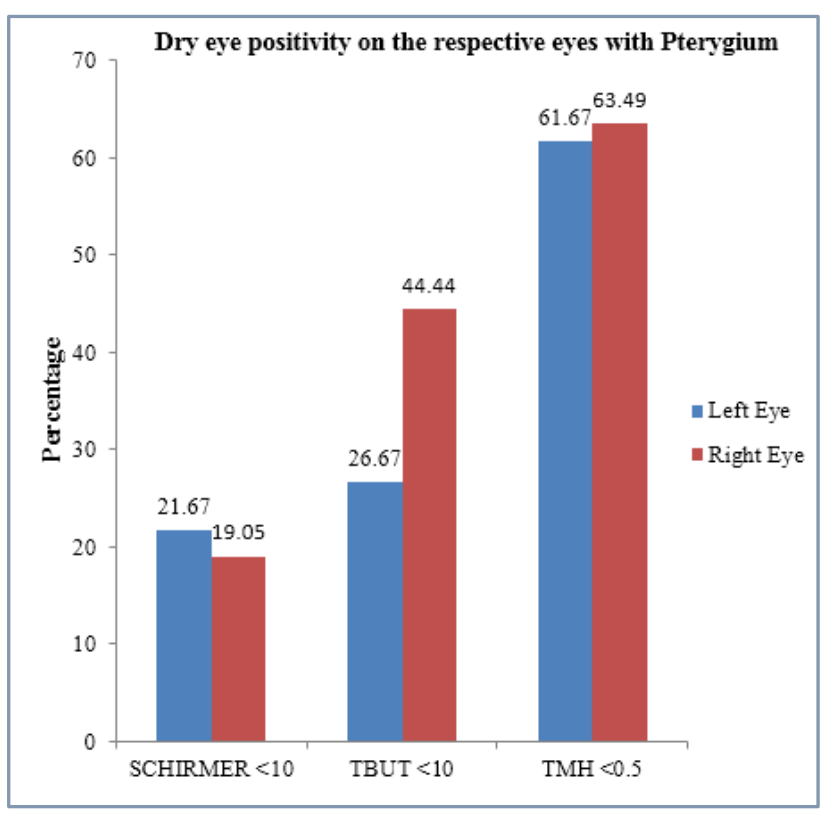

Figure 1. Bar Chart showing Dry Eye Positivity on the Respective Eyes with Pterygium

\begin{tabular}{|c|c|c|c|c|c|c|c|}
\hline \multicolumn{7}{|c|}{ Dry Eye Examination: Mean Value } \\
\hline Gender & RSCHIRMR & LSCHIRMR & RTBUT & LTBUT & RTMH & LTMH \\
\hline Overall & 16.7 & 18.0 & 10.2 & 10.7 & 0.4 & 0.4 \\
\hline Male & 15.9 & 17.0 & 10.4 & 11.4 & 0.4 & 0.4 \\
\hline Female & 17.2 & 18.4 & 10.1 & 10.3 & 0.4 & 0.4 \\
\hline \multicolumn{7}{|c|}{ Age (Overall) } \\
\hline $\begin{array}{c}<=35 \\
\text { years }\end{array}$ & 21.0 & 22.4 & 11.0 & 11.0 & 0.6 & 0.5 \\
\hline $36-45$ & 16.8 & 17.9 & 9.8 & 11.6 & 0.4 & 0.4 \\
\hline $46-55$ & 21.7 & 21.5 & 10.8 & 10.3 & 0.4 & 0.4 \\
\hline $56-65$ & 13.7 & 15.8 & 9.1 & 9.4 & 0.4 & 0.4 \\
\hline $\begin{array}{c}>65 \\
\text { years }\end{array}$ & 13.7 & 15.3 & 11.0 & 11.9 & 0.4 & 0.3 \\
\hline \multicolumn{7}{|c|}{ Age and Gender Male } \\
\hline $\begin{array}{c}<=35 \\
\text { years }\end{array}$ & 14.0 & 14.0 & 15.0 & 15.0 & 0.5 & 0.5 \\
\hline $36-45$ & 17.1 & 19.4 & 10.0 & 12.2 & 0.5 & 0.5 \\
\hline $46-55$ & 21.0 & 22.0 & 11.3 & 10.0 & 0.4 & 0.3 \\
\hline $56-65$ & 13.8 & 15.0 & 10.6 & 11.9 & 0.3 & 0.4 \\
\hline $\begin{array}{c}> \\
\text { years }\end{array}$ & 13.2 & 12.6 & 9.0 & 9.6 & 0.4 & 0.4 \\
\hline \multicolumn{7}{|c|}{ Age and Gender Female } \\
\hline $\begin{array}{c}<=35 \\
\text { years }\end{array}$ & 25.0 & 27.7 & 11.7 & 11.7 & 0.6 & 0.4 \\
\hline $36-45$ & 16.4 & 16.0 & 9.6 & 10.7 & 0.3 & 0.3 \\
\hline \begin{tabular}{c}
$46-55$ \\
\hline $56-65$
\end{tabular} & 13.7 & 21.3 & 10.6 & 10.3 & 0.4 & 0.4 \\
\hline $\begin{array}{c}\text { > 65 } \\
\text { years }\end{array}$ & 13.9 & 16.7 & 12.0 & 13.0 & 0.4 & 0.3 \\
\hline $\begin{array}{c}\text { Table 2. Mean Values of Dry Eye Tests on Right Eye and } \\
\text { Left Eye (N= 85) }\end{array}$ \\
\hline
\end{tabular}

Statistically significant association was not found between the presence of Pterygium and the dry eye. Also, there was no association between size of Pterygium and dry eye. On studying different factors, age, TBUT showed a statistically significant association between Pterygium and dry eye. Dry eye test among the patients with Pterygium showed no association with gender, occupation, smoking, menopause, hypertension, diabetes mellitus and cataract.

\begin{tabular}{|c|c|c|c|c|c|c|c|c|}
\hline $\begin{array}{l}\text { Sl. } \\
\text { No. }\end{array}$ & \multicolumn{3}{|c|}{$\begin{array}{l}\text { Observed } \\
\text { Frequency } \\
\text { Table }\end{array}$} & & d.o.f. & \begin{tabular}{|c|} 
Chi- \\
Square \\
Value
\end{tabular} & $\begin{array}{c}\text { Critical } \\
\text { Value }\end{array}$ & Conclusion \\
\hline \multirow{8}{*}{1} & \multicolumn{3}{|c|}{$\begin{array}{c}\text { SCHIRMER } \\
\text { 'S }<10 \\
\text { (Dry Eye) }\end{array}$} & & \multirow{8}{*}{4} & \multirow{8}{*}{9.02} & \multirow{8}{*}{9.49} & \multirow{8}{*}{$\begin{array}{c}\text { P value } \\
0.06061 \\
\mathrm{p}>0.05 \\
\text { not } \\
\text { significant }\end{array}$} \\
\hline & Age & Yes & No & Total & & & & \\
\hline & $<=35$ & 0 & 5 & 5 & & & & \\
\hline & $36-45$ & 5 & 12 & 17 & & & & \\
\hline & $46-55$ & 3 & 17 & 20 & & & & \\
\hline & 56-65 & 10 & 16 & 26 & & & & \\
\hline & $>65$ & 9 & 8 & 17 & & & & \\
\hline & \begin{tabular}{|l} 
Total \\
\end{tabular} & 27 & 58 & 85 & & & & \\
\hline \multirow{5}{*}{2} & & \multicolumn{2}{|c|}{$\begin{array}{c}\text { RPTRGY } \\
>0 \\
\text { (Dry Eye) }\end{array}$} & & \multirow{5}{*}{1} & \multirow{5}{*}{4.786} & \multirow{5}{*}{3.84} & \multirow{5}{*}{$\begin{array}{c}\mathrm{P} \text { value } \\
0.02861 \\
\mathrm{p}<0.05 \\
\text { significant }\end{array}$} \\
\hline & RTBUT & Yes & No & \begin{tabular}{|l|} 
Total \\
\end{tabular} & & & & \\
\hline & $<10$ & 28 & 4 & 32 & & & & \\
\hline & $>=10$ & 35 & 18 & 53 & & & & \\
\hline & Total & 63 & 22 & 85 & & & & \\
\hline
\end{tabular}

Table 3. Association between Age and Dry Eye Examination among Pterygium Patients

\begin{tabular}{|c|c|c|}
\hline $\begin{array}{c}\text { Correlation } \\
\text { Between }\end{array}$ & $\begin{array}{c}\text { Pearson's } \\
\text { Correlation } \\
\text { Value }\end{array}$ & Remarks \\
\hline RSCHIRMR - RPTRGY & 0.150300326 & $\begin{array}{c}\text { Very weak positive } \\
\text { correlation }\end{array}$ \\
\hline RTBUT - RPTRGY & -0.347014415 & $\begin{array}{c}\text { Weak negative } \\
\text { correlation }\end{array}$ \\
\hline RTMH - RPTRGY & -0.018739908 & Negligible correlation \\
\hline LSCHIRMR - LPTRGY & -0.117471479 & $\begin{array}{c}\text { Very weak negative } \\
\text { correlation }\end{array}$ \\
\hline LTBUT - LPTRGY & 0.020035023 & Negligible correlation \\
\hline LTMH - LPTRGY & -0.110389555 & $\begin{array}{c}\text { Very weak negative } \\
\text { correlation }\end{array}$ \\
\hline Table 4. Pearson's Correlation Dry Eye Test Values and \\
\multicolumn{2}{|c|}{ Size of Pterygium } \\
\hline
\end{tabular}

\section{DISCUSSION}

Proportion of Dry Eye Condition in the Patients with Pterygium

Based on Schirmer's Test- $19.04 \%$ of right eyes with Pterygium and $21.66 \%$ of left eyes with Pterygium have dry eye. So on an average, $20.32 \%$ of eyes with Pterygium have dry eye. Different studies show a wide range from $8.00 \%$ to $52.00 \%$.

\begin{tabular}{|c|c|c|c|c|c|}
\hline $\begin{array}{c}\text { Present } \\
\text { Study }\end{array}$ & Goldberg $^{3}$ & Roka N $^{4}$ & Ranjana $^{5}$ & Atiya $^{6}$ & Balogun $^{7}$ \\
\hline $20.32 \%$ & $52.54 \%$ & $31.57 \%$ & $8.00 \%$ & $9.30 \%$ & $31.20 \%$ \\
\hline \multicolumn{5}{|c|}{ Dry Eye Condition based on Schirmer's Test } \\
\hline
\end{tabular}

\section{Based on TBUT}

$44.40 \%$ of right eyes with Pterygium and $26.66 \%$ of left eyes with Pterygium have dry eye. On average, dry eye is seen in 
$35.77 \%$ of eyes with Pterygium. Different studies show range from $30.00 \%$ to $75.60 \%$.

\begin{tabular}{|c|c|c|c|c|c|c|}
\hline $\begin{array}{c}\text { Present } \\
\text { Study }\end{array}$ & Goldberg $^{3}$ & Roka N $^{4}$ & Ranjana $^{5}$ & Atiya $^{6}$ & Balogun $^{7}$ & $\begin{array}{c}\text { Ameer } \\
\mathbf{Y}^{8}\end{array}$ \\
\hline $35.77 \%$ & $50.84 \%$ & $43.42 \%$ & $30.00 \%$ & $75.60 \%$ & $39.70 \%$ & $47.20 \%$ \\
\hline \multicolumn{5}{|c|}{ Dry Eye Condition based on TBUT } \\
\hline
\end{tabular}

\section{Based on TMH}

$63.49 \%$ of right eyes with Pterygium and $61.66 \%$ of left eyes with Pterygium have dry eye. On an average, $62.60 \%$ of eyes with Pterygium have dry eye.

\begin{tabular}{|c|c|}
\hline Present Study & Muhammad Saleem $^{9}$ \\
\hline $62.60 \%$ & $37.50 \%$ \\
\hline \multicolumn{2}{|c|}{ Dry Eye Condition based on TMH } \\
\hline
\end{tabular}

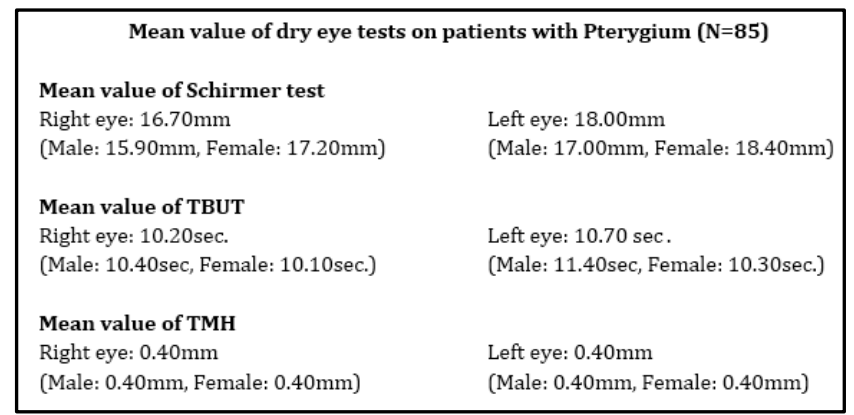

Mean value of dry eye test in the case of unilateral Pterygium

\begin{tabular}{|c|c|c|c|c|c|}
\hline \multicolumn{2}{|c|}{ Present Study } & \multicolumn{2}{|c|}{ Kampitak10 $^{10}$} & \multicolumn{2}{|c|}{ Chaidaroon 11} \\
\hline R. Eye & $\begin{array}{c}\text { Opposite Normal } \\
\text { Eye }\end{array}$ & $\begin{array}{c}\text { Eyes } \\
\text { with Pterygium }\end{array}$ & $\begin{array}{c}\text { Opposite Normal } \\
\text { Eye }\end{array}$ & $\begin{array}{c}\text { Eyes } \\
\text { with Pterygium }\end{array}$ & $\begin{array}{c}\text { Opposite Normal } \\
\text { Eye }\end{array}$ \\
\hline $18 \mathrm{~mm}$ & $19 \mathrm{~mm}$ & \multirow{4}{*}{$9.8 \mathrm{~mm}$} & \multirow{4}{*}{$10 \mathrm{~mm}$} & \multirow{4}{*}{$11.60 \mathrm{~mm}$} & \multirow{4}{*}{$12.4 \mathrm{~mm}$} \\
\hline & with Pterygium & & & & \\
\hline L. Eye & Opposite Normal Eye & & & & \\
\hline $18 \mathrm{~mm}$ & $17 \mathrm{~mm}$ & & & & \\
\hline
\end{tabular}

\begin{tabular}{|c|c|c|c|c|c|}
\hline \multicolumn{2}{|c|}{ Present Study } & \multicolumn{2}{|c|}{ Kampitak10 $^{10}$} & \multicolumn{2}{|c|}{ Balogun 7} \\
\hline Right Eye & $\begin{array}{l}\text { Opposite Normal } \\
\text { Eye }\end{array}$ & Eyes with Pterygium & $\begin{array}{c}\text { Opposite Normal } \\
\text { Eye }\end{array}$ & Eyes with Pterygium & $\begin{array}{c}\text { Opposite Normal } \\
\text { Eye }\end{array}$ \\
\hline 9 sec. & $10 \mathrm{sec}$. & \multirow{4}{*}{$5.5 \mathrm{sec}}$. & \multirow{4}{*}{$11.30 \mathrm{sec}}$. & \multirow{4}{*}{$17 . .90 \mathrm{sec}}$. & \multirow{4}{*}{$19.86 \mathrm{sec}}$. \\
\hline \multicolumn{2}{|c|}{ Left Eye with Pterygium } & & & & \\
\hline Left Eye & $\begin{array}{l}\text { Opposite Normal } \\
\text { Eye }\end{array}$ & & & & \\
\hline $11 \mathrm{sec}$. & $11 \mathrm{sec}$. & & & & \\
\hline \multicolumn{6}{|c|}{ Mean Value of TBUT } \\
\hline
\end{tabular}

Range of Dry Eye Tests

Range of Schirmer's test

$1 \mathrm{~mm}$ to $35 \mathrm{~mm}$

\begin{tabular}{|c|c|c|c|}
\hline Present Study & Rajiviv $^{\mathbf{2}}$ & Muhammad Saleem $^{9}$ & Roka N$^{\mathbf{4}}$ \\
\hline $1 \mathrm{~mm}$ to $35 \mathrm{~mm}$ & $3 \mathrm{~mm}$ to & $3 \mathrm{~mm}$ to $14 \mathrm{~mm}$ & $2.50 \mathrm{~mm}$ to \\
& $9.4 \mathrm{~mm}$ & $\mathrm{~mm}$ \\
\hline
\end{tabular}

\section{Range of TBUT}

3 seconds to 20 seconds.

\begin{tabular}{|l|c|c|}
\hline Present Study & Muhammad Saleem & Roka N \\
\hline 3 sec. to $20 \mathrm{sec}$. & 3 sec. to $14 \mathrm{sec}$. & 2.5 sec. to $27.50 \mathrm{sec}$. \\
\hline
\end{tabular}

\section{Correlation between Dry eye and size of Pterygium}

The present study found weak or negligible correlation between dry eye and size of Pterygium. This agrees with the observation by Kampitak et al.10

\section{CONCLUSION}

On the basis of different criteria, at least $20.32 \%$ of eyes with Pterygium (either unilateral or bilateral) are affected with dry eye. The tests showed different proportions of dry eye condition among the patients with Pterygium:

Schirmer's Test : $\quad 20.32 \%$

TBUT : $\quad 35.77 \%$

TMH : $\quad 62.60 \%$
Age showed no association with dry eye.

\section{ACKNOWLEDGEMENT}

All the patients who participated in the study.

\section{REFERENCES}

[1] Duke-Elder S. System of ophthalmology. London: Henry Kimpton, 1977;(VIII):134-48.

[2] Sihota R, Tandon R. Parson's diseases of the eye. 22 ${ }^{\text {nd }}$ edn. New Delhi: Elsevier, 2015;(14):184-5.

[3] Goldberg L, David R. Pterygium and its relationship to the dry eye in the Bantu. Br J Ophthalmol 1976;60(10):720-1.

[4] Roka N, Shrestha SP, Joshi ND. Assessment of tear secretion and tear film instability in cases with pterygium and normal subjects. Nepal J Ophthalmol 2013;5(1):16-23.

[5] Ranjana B, Dipanwita N, Santhosh KM, et al. Ocular surface disorder in pterygium: role of conjunctival impression cytology. Indian J Pathol Microbiol 2010;53(4):692-5.

[6] Rahman A, Yahya K, Fasih U, et al. Comparison of Schirmer's test and tear film break up time test to detect tear film abnormalities in patients with pterygium. J Pak Med Assoc 2012;62(11):1214-6.

[7] Balogun MM, Ashaye AO, Agayi BG, et al. Tear breakup time in eyes with pterygia and pingueculae in Ibadan. West Afr J Med 2005;24(2):162-6. 


\section{Jemds.com}

[8] Amer YR. Evaluation of tear film stability in pterygium and pingueculae. Ann Coll Med Mosul 2013;39(2):1325.

[9] Saleem M, Muhammad L, Islam ZU. Pterygium and dry eye: a clinical study. JPMI 2004;18(4):558-62.

[10] Kampitak K, Leelawongtawun W. Precorneal tear film in pterygium eye. J Med Assoc Thai 2014;97(5):536-9.

\section{Original Research Article}

[11] Chaidaroon W, Pongmoragot N. Basic tear secretion measurement in pterygium. J Med Assoc Thai 2003;86(4):348-52.

[12] Rajiv, Mithal S, Sood AK. Pterygium and dry eye-a clinical correlation. Indian J Ophthalmol 1991;39(1):15-6. 